\title{
EFFECT OF DIFFERENT DIMENSIONS OF ORGANIZATIONAL CULTURE ON JOB SATISFACTION OF NURSES WORKING IN RURAL AREAS OF PUNJAB, PAKISTAN
}

Iqra Nawaz $^{1 *}$, Ashfaq Ahmed Maan ${ }^{2}$, Izhar Ahmad Khan ${ }^{3}$, Babar Shahbaz ${ }^{4}$

${ }^{1 *} \mathrm{Ph} . \mathrm{D}$. Scholar, Department of Rural Sociology, University of Agriculture, Faisalabad, Pakistan; ${ }^{2}$ Retired Professor of Department of Rural Sociology, University of Agriculture, Faisalabad, Pakistan; ${ }^{3}$ Associate Professor, Department of Rural Sociology, University of Agriculture, Faisalabad, Pakistan; ${ }^{4}$ Associate Professor, Department of Agri Extension and Rural Development, University of Agriculture, Faisalabad, Pakistan.

Email: ${ }^{1 *}$ iqranawaz21@gmail.com, ${ }^{2}$ ashfaqmaan@ gmail.com, ${ }^{3}$ izhark99@gmail.com, ${ }^{4}$ bsuaf@yahoo.com

Article History: Received on $12^{\text {th }}$ March 2021, Revised on $28^{\text {th }}$ April 2021, Published on $29^{\text {th }}$ April 2021

\section{Abstract}

Purpose of the study: The current study has explored the effect of different dimensions of organizational culture on the job satisfaction of nurses working in the rural areas of Punjab, Pakistan.

Methodology: Present study used a cross-sectional, face-to-face approach. The researcher collected data from 452 nurses working at tehsil headquarter hospitals and rural health centres across Punjab with the help of an interview schedule. The effect of culture on the job satisfaction level of nurses Investigated with the help of Multiple regression techniques.

Main Findings: The analysis showed a $52 \%$ variation in job satisfaction because of the culture. Values and belief systems, feedback systems, innovation, growth and development opportunities, relationship patterns, autonomy, work environment were the significant determinants of job satisfaction. Whereas the facilities, communication, and vision were the nonsignificant determinants of job satisfaction in the present study.

Application of this study: The current research will be helpful to understand the prevailing culture of health care organizations. That will help the administrators and policymakers to understand the different factors which are responsible for low productivity.

Novelty /originality of this study: The study is novel in organizational studies because it adopts a holistic approach to consider all the significant components of culture.

Keywords: Organizational Culture, Job Satisfaction, Rural Health Centres, Tehsil-headquarter Hospitals.

\section{INTRODUCTION}

Pakistan is a developing country with minimal budgetary allocation for the health care system. $63.1 \%$ of the population lives in rural areas (Population Census, 2017). After the Alma-Ata declaration in 1978, Pakistan has started to expand its health care facilities to rural areas. Poverty, increasing burden of diseases, lack of quality health care facilities, and a population with a rich number of youngsters and older people are the challenges the health care system must face. Furthermore, the health care system also must face the issue of brain drain. Health care facilities have expanded many folds. But this expansion of services undermines many vital aspects of planning, management, and development of human resources. Pakistan is among the list of 57 countries facing the human resource crisis in health care services. Most of the health care service providers preferred to serve in urban areas. Currently, for 3,626 people, there is one nurse (WHO, 2011). Human resources are significant to pursue the organization's goals. Nurses are the backbone of the health care system. Globally the focus is shifting from secondary (treatment) health care to primary. Nurses could be an essential part of this critical health care workforce.

Educated and well-trained nurses can serve the best alternate to doctors in rural areas. WHO (2011) acknowledged that job satisfaction and motivation at the workplace are critical factors. These factors reduce turnover intentions. It is necessary to understand such factors. Job dissatisfaction has drastic impacts on employees like high turnover, low productivity. The environment in which employees performed plays a significant role in the satisfaction of the employees. The system of shared values, beliefs, and norms made the culture and affect the thinking of the employees that how they will behave and feel within that organization (Schein, 2004). The culture of an organization holds power to increase the productivity of its employees, levels of their satisfaction with their profession and provide its members with confidence that they can solve their problems at the workplace. The culture of an organization can be used as an instrument to provide direction. It helps to understand the problems and events of the organization. That will ensure a sense of order among its members. Job satisfaction is productive for the organization in which the employee works and contributes towards the employee's physical health, longevity, and mental health (Locke, 1976). The present study was designed to explore the role of different dimensions of culture on the job satisfaction level of nurses providing services in rural areas of Punjab, Pakistan. 


\section{LITERATURE REVIEW}

Shared cognitions among the members of an organization is called its culture (Smircich, 1983). It has multiple dimensions and levels (Tharp (2009). An organization's culture reflects its purpose and foundations (Gutknect and Miller, 1990). It is reflected in the tangible things, values, and underlying assumptions of an organization (Schein, 2004) and manifested into the behavioural norms and expectations (Balthazard et al., 2006).

A culture that focuses on learning and goal orientation can increase employee's commitment and job satisfaction (Joo and Park, 2009). The culture holds the power to increase its employees' job satisfaction by improving their performance (Kotter, 2012). An organization's culture increases job commitment, bringing higher job satisfaction and improving performance (Nahar et al.,2020). The culture of an organization is the motivating force for its employees that brings excellent performance. The learning culture, feedback system, and orientation affect the employees' commitment to their job. (Huang and Chi, 2004). The culture of an organization, working environment, and leadership styles are significantly associated with job satisfaction (Pawirosumarto et al., 2017). The culture of an organization and leadership style affect the performance of the employees. A good leadership style increases Job satisfaction.

Job satisfaction is positive or negative feelings about one's job (Schermerhorn, 2000). Working conditions that allow the fulfillment of desired needs, gratitude, and equity are said to be the attributes of job satisfaction (Liu et al., 2016). Warmth among colleagues, trust, respect, and relations among employees and superiors are the most critical factors in job satisfaction (Kennerly, 1989). Financial aspects, available equipment, public appreciation, and relationships also affect job satisfaction (Xuan Tran et al., 2013). The flawed evaluation system, lack of opportunities for professional training, poor working conditions, and low wages contribute to job satisfaction (Mengistu and Bali, 2015). Koustelios (1996) said that conditions at the workplace, relationships with other colleagues, promotion opportunities, and institutions affect job satisfaction. Higher autonomy results in higher job satisfaction and happiness (Hwang, 2018; Liu et al., 2016). Freeborn and Hooker (1995) reported a sense of responsibility, coworker's support, job security, working hours, supervisory support, and variety in task performance increased job satisfaction. workload, control at the workplace, and advancement opportunities decreased job satisfaction. Ahmed et al., (2010) reported recognition for one's job, nature of work, advancement opportunities, and a sense of responsibility as the main contributory factors of job satisfaction.

Witter et al., (2011) reported lower satisfaction at lower placement levels because of less sophisticated equipment, lack of opportunities for skill development, less experienced colleagues, and needy clients. Sufficient resources and flexible work environments affect the retention rates of its employees (Kossivi et al., 2016). The ability to empower others, align visions, and coordinate efficient communication strategies supports creativity and innovation (Hynes \& Mickahail, 2019).

Ahmadi and Alireza (2007) said that lack of work-life balance, advancement opportunities, encouragement, recognition, and working environment lower job satisfaction. Job satisfaction can affect the retention rate of employees. Organizations with good culture and financial benefits ensure success in the marketplace and delighted workers with high retention rates (Igbal et al., 2017). Feedback plays an essential role in the employees' learning and development (Zhou, 2003). And positive feedback results in increased job satisfaction by improving competency and refined ways for task performance (Jaworski and Khol, 1991). Lok and Crawford (1999) explored the relationship between innovation, commitment, and job satisfaction. Control over the work environment, relationship with other colleagues, and professionalism are the indicators of job satisfaction and are strongly associated with a job commitment. Loose supervision and reward achievement increased job satisfaction (Robbins, 1996). Carriere and Bourque (2009) reported communication as a source of variation in job satisfaction. Communication is a tool through which an organization transfers its culture to the members (Gochhayat et al., 2017). Job satisfaction is affected by an organization's communication, leadership style, and culture (Komah et al., 2019). Arabshahi and Arabshahi (2014) said effective communication causes a higher level of job satisfaction. Managers can popularize the collectivist culture by focusing on teamwork orientation. It will minimize the effect of individual values (Mustafa et al.,2017).

An organization's culture positively and significantly affects employee performance and job satisfaction (Maulidiyah, 2018). Kim et al., (2016) also assert that the organization's culture, marital status, age, experience, and nurse's job commitment all affect the job satisfaction level of nurses. So, assessment of the culture helps leaders highlight areas where improvement is needed (McElory et al., 2016). In the present study, it is supposed that different dimensions of culture affect the job satisfaction level of nurses of rural areas of Punjab, Pakistan.

\section{MATERIAL AND METHODS}

\section{Data}

The present study used a cross-sectional, face-to-face approach. The researcher collected data from 452 nurses working at tehsil headquarter hospitals and rural health centres across Punjab with the help of an interview schedule. All the nurses working at Tehsil headquarter hospitals and Rural health centres of Punjab province, Pakistan, was the population. Punjab is the most populous province and has 36 Districts and 127 tehsils and towns. Total 318 Rural health centres and 128 Tehsil headquarter hospitals are working. Out of which, the present study selected 12 Tehsils 
headquarters hospitals and 45 Rural Health centres. To meet the minimum criteria of the sample. Interview conducted with 452 nurses. This study used an interview schedule with three parts, socio-demographic features, and variables to assess organizational culture and job satisfaction. Table 1 presents the socio-demographic characteristics of the nurses who participated in the study.

Table 1: Socio-Demographic characteristics

\begin{tabular}{|c|c|c|c|}
\hline & & Frequency & Percentage \\
\hline \multirow{5}{*}{ Qualification } & Matric & 243 & $53.8 \%$ \\
\hline & Intermediate & 75 & $16.6 \%$ \\
\hline & Bachelor & 116 & $25.7 \%$ \\
\hline & Masters & 16 & $3.5 \%$ \\
\hline & Above & 2 & $.4 \%$ \\
\hline \multirow{4}{*}{ professional qualification } & Diploma Nursing & 391 & $86.5 \%$ \\
\hline & Postgraduate diploma & 25 & $5.5 \%$ \\
\hline & $\mathrm{R} N$ nursing & 34 & $7.5 \%$ \\
\hline & MS nursing & 2 & $.4 \%$ \\
\hline \multirow{4}{*}{ Marital status } & Single & 130 & $28.8 \%$ \\
\hline & Married & 319 & $70.6 \%$ \\
\hline & Widow & 1 & $.2 \%$ \\
\hline & Divorced & 2 & $.4 \%$ \\
\hline \multirow{5}{*}{ Age } & Under 20 years & 18 & $4.0 \%$ \\
\hline & 21 to 30 years & 220 & $48.7 \%$ \\
\hline & 31 to 40 & 149 & $33.0 \%$ \\
\hline & 41 to 50 & 43 & $9.5 \%$ \\
\hline & 51 to 60 & 22 & $4.9 \%$ \\
\hline \multirow{6}{*}{ Length of service } & $1-5$ years & 207 & $45.8 \%$ \\
\hline & $6-10$ years & 142 & $31.4 \%$ \\
\hline & $10-15$ years & 48 & $10.6 \%$ \\
\hline & $16-20$ years & 8 & $1.8 \%$ \\
\hline & 21-25 year & 27 & $6.0 \%$ \\
\hline & Above & 20 & $4.4 \%$ \\
\hline
\end{tabular}

\section{Data and Data analysis}

Bartlett's test of sphericity and Kaiser-Meyer-Olkin tests were performed. The KMO value of .93 is superb (Hutcheson and Sofroniou, 1999) and support factor analysis. Principal component analysis grouped the 50 items related to the organization's culture into ten factors. The significance level of .000 of chi-square suggests the correlation of construct items and supports factor analysis. Data were analyzed through SPSS 16.0 version.

Table 2: Kaiser-Meyer-Olkin and Bartlett's Test

\begin{tabular}{llll}
\hline & & \multicolumn{2}{l}{ Bartlett's test of sphericity } \\
\cline { 3 - 4 } Construct & Kaiser-Meyer-Olkin & Chi-square & Sig. \\
\hline Organizational culture & .936 & 1225 & .000 \\
\hline
\end{tabular}

The dimensions of the organization's culture assessed in the present study include physical settings and facilities, autonomy, relationship patterns, vision and mission of the organization, communication system, growth and development opportunities, innovation, feedback system, values, and beliefs. Each concept contains several variables, the index scale developed for each concept. The details of each scale are: Physical settings and facilities scale contains five items each. The concept of autonomy was assessed through six questions. The vision and mission construct used three sub-items. Communication scale developed with two items. The concept of growth and development opportunities were assessed through nine questions.

Relationship patterns and innovation within cultures were assessed on five items for each. The feedback system was assessed through five items, and three variables assessed the values and beliefs system. All the items were measured on a five-point Likert scale from 1 to 5. Respondents were asked to rate how much each item is practised in their workplace. The job satisfaction section contains twelve items on both external and internal aspects of job satisfaction of nurses. The responses were collected on five points Likert scale. Numbers assign from 1 to 5 to rate how much they are satisfied. One for strongly disagree, 2 for disagree, 3 for neutral, 4 for agree, and 5 for rating to strongly agree.

Cronbach's alpha values were also calculated to ensure the internal validity of the construct.

Table 3: Reliability

\begin{tabular}{llll}
\hline Scale variable & N & No of Items & Cronbach's alpha value \\
\hline
\end{tabular}




\begin{tabular}{llll}
\hline Organizational culture & 452 & 50 & .904 \\
\hline Job satisfaction & 452 & 12 & .889 \\
\hline
\end{tabular}

\section{Empirical Findings and Discussion}

The results of the study are reported in two parts. Descriptive statistics used mean scores, standard deviations, and midpoints. Scores of each subject on a particular variable are calculated by averaging the subject's ratings on the set of items corresponds to that variable. The "scale midpoints" values correspond to the centre of the rating scale used for items in that scale. The second part used the principal component analysis and Regression analysis to determine the effect of each component of organizational culture on job satisfaction levels among nurses.

Table 4: Descriptive Statistics

\begin{tabular}{llll}
\hline Scale & Mean Score & Standard Deviation & Scale Mid-point \\
\hline Physical settings & 2.513 & .58 & 2.5 \\
Facilities available & 2.433 & .59 & 2.5 \\
Autonomy & 2.57 & .629 & 2.5 \\
Relationship patterns & 2.42 & .589 & 2.5 \\
Vision and mission & 2.86 & .377 & 2.5 \\
Communication & 2.57 & .608 & 2.5 \\
Growth and development opportunities & 2.62 & .526 & 2.5 \\
Innovativeness & 2.55 & .557 & 2.5 \\
Feedback system & 2.43 & .563 & 2.5 \\
Values and beliefs system & 2.85 & .370 & 2.5 \\
Job satisfaction & 2.55 & .565 & 2.5 \\
\hline
\end{tabular}

The mean score and standard deviation for each scale are calculated. The values of available facilities, relationship patterns, and feedback systems are below the midpoint of the rating scale. It indicates that nurses scored low on these dimensions of the culture of their organizations. The mean score for job satisfaction level (2.55) is also among the midpoint of the rating scale.

Principal component analysis performed. Total 10.0 factors retained with greater than 1.0 Eigenvalue criteria.

Table 5: Factor Loadings

\begin{tabular}{|c|c|c|}
\hline Culture Dimension & Item & $\begin{array}{l}\text { Factor } \\
\text { Loading }\end{array}$ \\
\hline \multirow[t]{5}{*}{ Work Environment } & Physical settings & .686 \\
\hline & Cleanliness & .674 \\
\hline & health-related Safety measures & .657 \\
\hline & Weather & .707 \\
\hline & Personal safety measures & .724 \\
\hline \multirow[t]{5}{*}{ Facilities } & Equipment & .750 \\
\hline & Ventilation & .750 \\
\hline & Workspace & .717 \\
\hline & Power supply & .717 \\
\hline & Drinking water & .676 \\
\hline \multirow[t]{6}{*}{ Autonomy } & Change of office settings & .605 \\
\hline & Decision making & .629 \\
\hline & Participation in decision making & .721 \\
\hline & Decision's incorporation & .740 \\
\hline & Problem sharing with supervisor & .709 \\
\hline & Supervisor response to the shared problems & .734 \\
\hline \multirow[t]{6}{*}{ Relationship patterns } & Sharing with other nurses & .675 \\
\hline & Sharing with supervisor & .774 \\
\hline & A friendly and collaborative work environment with other nurses & .635 \\
\hline & $\begin{array}{l}\text { A friendly and collaborative work environment with doctors and } \\
\text { paramedics }\end{array}$ & .609 \\
\hline & Understanding the expectations of head nurse & .677 \\
\hline & Response of the colleagues to the individual differences & .580 \\
\hline \multirow[t]{3}{*}{ Vision and Mission } & Core values and work-related ethics & .728 \\
\hline & Preferences for quality care & .686 \\
\hline & Quality care as a motivational force & .670 \\
\hline Communication system & Timely discharge of orders & .667 \\
\hline
\end{tabular}




\begin{tabular}{|c|c|c|}
\hline & Periodical meetings for sharing and learning purposes & .681 \\
\hline \multirow{10}{*}{$\begin{array}{l}\text { Personal growth and } \\
\text { development }\end{array}$} & Personal competence & .557 \\
\hline & Expressions of professional skills & .682 \\
\hline & Appreciation from the head nurse & .690 \\
\hline & Appreciation from patients and their relatives & .764 \\
\hline & Appreciation from other staff & .695 \\
\hline & Hospitals support learning and mastering of new skills & .714 \\
\hline & Fear for reporting of mistakes & .618 \\
\hline & Response to mistakes for future & .633 \\
\hline & Sharing of mistakes with others so they can learn from experience & 617 \\
\hline & The attitude of learning rather than blaming & .605 \\
\hline \multirow[t]{5}{*}{ Innovation } & Out of box thinking & .694 \\
\hline & Application of new knowledge and skills & .608 \\
\hline & The response of head nurses towards new skills & .650 \\
\hline & The response of other staff nurses towards new skills & .564 \\
\hline & $\begin{array}{l}\text { The response of doctors towards utilization of new knowledge and } \\
\text { skills }\end{array}$ & .700 \\
\hline \multirow[t]{6}{*}{ Feedback System } & A well-established evaluation system & .721 \\
\hline & The reward for best performance & .676 \\
\hline & Fair and impartial feedback & 663 \\
\hline & Regular feedback from supervisor & .638 \\
\hline & Ideas and involvement for the better work environment & .539 \\
\hline & The attitude of problem-solving rather than blaming & .719 \\
\hline \multirow[t]{2}{*}{ Values and Beliefs } & Teamwork for the attainment of objectives & .660 \\
\hline & Sense of personal responsibility for duty & .485 \\
\hline
\end{tabular}

Total ten factors retained. Retained factors accounted for the $66.72 \%$ variance. The detail of each factor loading is mentioned in the table: 5 above - all items related to 10 principal components of organizational culture range from .774 to .485 . Regression analysis was performed to see the effect of each factor related to organizational culture on job satisfaction levels.

Table 6: Model Summary

\begin{tabular}{llllll}
\hline R & R square & Adjusted-R square & Std. Error & F. statistics & Prob. \\
\hline $\mathbf{. 7 2 2}$ & .522 & .512 & .395 & 53.590 & 0.000 \\
\hline
\end{tabular}

Predictor: Organizational Culture

Dependent Variable: Job Satisfaction

In the above table of model summary, the R-square value of .522 explains that all the ten independent variables related to organizational culture explain 52\% variation in the dependent variable of job satisfaction level. The F-value of 53.590 and P-value of 0.000 shows the combined effect of all components of organizational culture on job satisfaction.

Table 7: Regression Coefficients

\begin{tabular}{lllll}
\hline Regressor & Beta Coefficients & Std. Error & t-Ratio & Sig. \\
\hline Constant & -.214 & .174 & 2.045 & .219 \\
\hline Work environment & .095 & .046 & 0.829 & .041 \\
\hline Facilities & .037 & .045 & 2.476 & .408 \\
\hline Values \& beliefs & .156 & .063 & 2.157 & .014 \\
\hline Feedback & .095 & .044 & 4.024 & .032 \\
\hline Innovativeness & .204 & .051 & 3.086 & .000 \\
\hline Growth \& development & .166 & .054 & 1.920 & .002 \\
\hline Communication & .094 & .049 & 1.875 & .056 \\
\hline Vision and mission & .116 & .062 & -2.044 & .061 \\
\hline Relationships & -.085 & .042 & 3.338 & .042 \\
\hline Autonomy & .145 & .046 & 3.417 & .001 \\
\hline
\end{tabular}

The work environment of the nurses shows a significant effect on the job satisfaction level with a beta value of .095 . Applebaum et al., (2010) also reported that stressors in the surrounding environment result in decreased job satisfaction among nurses. The findings are in line with Mengistu and Bali (2015), Koustelios (1996), and Tumulty et al., (1994). Available facilities at the workplace have a nonsignificant effect (.037). 
Beta value (.156) indicates a significant relation of the values and belief system with the job satisfaction level of nurses. Commonly held values and beliefs systems enhance the job satisfaction of nurses.

The beta value (.095) indicates a significant and positive relationship between feedback and the job satisfaction level of the nurses in the current study. An efficient and up-to-date system of feedback is affecting the job satisfaction of nurses. Joo and Park (2009); Mengistu and Bali (2015) reported consistent findings. Hackman and Oldman (1975) suggest further the dimension of feedback and its effect. Job's features and employee's behaviour are affected by three psychological aspects: the meaningfulness of their work, how much they are responsible for the outcomes of their work, and the result-related feedback. Zhou (2003) report the role of feedback from the supervisor on the development. It helps the employees to learn, develop and improve his/her skills related to the job, which will bring satisfaction from the job. Jaworski and Kohl (1991) study reported that the supervisors provide their employees with positive feedback. Their employees were more able to learn how to do things better, reinforce proper behaviours, improve incompetence, and raise their satisfaction for performance in sales marketing.

The beta value of .204 indicates a significant and positive association between the innovativeness feature of the organizational culture and job satisfaction level among nurses. Nurses are satisfied with their work within organizations having innovativeness features. The findings are in line with Parker and Sprigg (1999). They reported that the presence of a support system and innovation in subcultures of an organization has a significant correlation with job commitment which leads towards greater job satisfaction. Lok and Crawford (1999) also reported that innovation and support in subcultures significantly correlate with the commitment that leads to job satisfaction. Zhang and Bartol (2010) said that a harmonious relationship between leader and employee could contribute to the organization's innovation, survival, performance, and effectiveness. So, the leader plays an instrumental role. Amabile (1998) and West (2002) said that innovation is the implementation of sound and novel ideas, the production process of these novel and valuable ideas are called creativity. Woodman et al., (1993) reported that the control stimulates creativity at the job place one holds. A supportive environment from colleagues and supervisors and creativity increased the employee mental well-being (Warr, 1994), which will bring more satisfaction.

The beta value of .166 is indicating a significant and positive association between the growth and development opportunities and job satisfaction level among nurses. Joo and Park (2009) reported "commitment of the employee with his or her organization strongly affected by the learning culture within the organization, and it leads toward the greater satisfaction. Mengistu and Bali (2015) reported the lack of professional training opportunities as a contributing factor of dissatisfaction with one's job. Robbins (1996) also reported the organization which rewards achievement and loose supervision causes higher satisfaction.

The beta value of .094 indicates a nonsignificant relationship between the communication systems prevailing in the tehsil headquarter hospitals and Rural health centres and job satisfaction level among nurses. It shows that the efficiency of the communication system had little impact on the level of job satisfaction among nurses in the present study. Carriere and Bourque (2009) study showed that the communication practices contributed $23.4 \%$ variations in job satisfaction. Pincus (1986) study also showed the strongest association among different aspects of communication and job satisfaction. Arabshahi and Arabshahi (2014) also reported that a more effective communication system causes a greater level of satisfaction among its employees.

The beta value of .116 indicates a positive but nonsignificant relationship among the understanding with the vision and mission of the culture and job satisfaction level. Understanding the vision and mission of the organization's culture has the least significant effect on the job satisfaction level of nurses. At the same time, Testa (1999) study results showed that vision accounts for $33 \%$ and $21 \%$ of the variance in job satisfaction. Fachrunnisa and Adhiatma (2014) stated that its employees play a crucial role in achieving the organization's vision and mission, and spiritual leaders understand the culture by calling. Membership will bring the organization's vision and mission vision, and value congruence. Fry (2003) proposed that a spiritual leader is a leader who bears a higher spirit and inspires his employees to achieve the vision and mission of the organization. Redding (1997) suggests that a learning organization is a collective form of activity through which the organization reached its shared vision.

The beta value of -.085 explains the negative and significant relationship between nurses' relationship patterns and job satisfaction levels. So, the more individualistic and distant relationship patterns an organization results in decreased job satisfaction levels among nurses. Lok and Crawford (1999) also reported relationships among colleagues as indicators of job satisfaction level. Kennerly (1989) is also reported an association between colleagues and job satisfaction. Koustelios (1996) also reported that the relationship with other colleagues is one factor that affects the satisfaction level of the job. Tumulty et al., (1994) reported that a group with close ties act as a compensatory mechanism for the other frustrations, and the supportive attitude of the manager act as a buffer for nurses from being affected by the less desirable environments.

The beta value of .154 explains the significant and positive relationship between the autonomy permitted within the premises of an organization and the satisfaction nurses felt within that organization. The more autonomous nurses were more satisfied with their jobs. Lok and Crawford (1999) also reported a strong association between job satisfaction and control over the work environment. Daniels and Bailey (1999) reported that participatory decision-making increase job 
satisfaction. Johnson and Mclntye, (1998) reported empowerment as a factor had significant impact on job satisfaction. learning and use of new knowledge and skills stimulated by control one has at its job place (Parker and Sprigg,1999).

\section{CONCLUSION}

Overall, the organizational culture has a substantial impact on the job satisfaction level of nurses. The multivariate analysis suggests innovativeness and opportunities for personal growth and development have a highly significant association with job satisfaction. Values and beliefs system, feedback system, relationship patterns, autonomy, and work environment are significant predictors of job satisfaction among nurses. Facilities, communication systems, and vision and mission have a nonsignificant role in the job satisfaction of the nurses working in rural areas of Punjab, Pakistan.

\section{RECOMMENDATIONS}

- Comparison and exploration of the culture and job satisfaction among tertiary care hospitals need to be assessed to formulate a complete picture of the health care organizational culture and job satisfaction.

- Policymakers and hospital administration should pay keen interest towards conscious creation of a culture that focuses not only on service delivery oriented approach but also on employee well-being.

- We need to popularize the learning culture among nurses by creating a supportive environment.

\section{LIMITATIONS OF THE STUDY}

The current study is limited to the nurses' perceptions about different dimensions of organizational culture of health care organizations and their effect on job satisfaction level.

\section{ACKNOWLEDGEMENT}

No agency funded the study. The author completed it as a part of her doctoral degree program. I acknowledged the efforts of Qamar Shahzad and Khalil Ur Rehman for helping me in data collection.

\section{AUTHORS CONTRIBUTION}

Study design: Iqra Nawaz, Ashfaq Ahmad Mann. Data collection: Iqra Nawaz. Data analysis: Iqra Nawaz. Manuscript preparation: Iqra Nawaz, Ashfaq Ahmad Mann, Izhar Ahmad Khan, Babar Shahbaz. Study supervision: Ashfaq Ahmad Mann, Izhar Ahmad Khan, Babar Shahbaz.

\section{REFERENCES}

1. Ahmadi, K., \& Alireza, K. (2007). Stress and Job Satisfaction among Air Force Military Pilots. Journal Of Social Sciences, 3(3), 159-163. https://doi.org/10.3844/jssp.2007.159.163

2. Ahmed, I., Nawaz, M. M., Iqbal, N., Ali, I., Shaukat, Z., \& Usman, A. (2010). Effects of motivational factors on employee's job satisfaction a case study of University of the Punjab, Pakistan. International Journal of business and management, 5(3), 70. https://doi.org/10.5539/ijbm.v5n3p70

3. Amabile, T. M. (1988). A model of creativity and innovation in organizations. Research in organizational behaviour, 10(1), 123-167.

4. Applebaum, D., Fowler, S., Fiedler, N., Osinubi, O., \& Robson, M. (2010). The impact of environmental factors on nursing stress, job satisfaction, and turnover intention. The Journal of nursing administration, $40(0)$, 323-328. https://doi.org/10.1097/NNA.0b013e3181e9393b

5. Arabshahi, M., \& Arabshahi, G. (2014). The relationship between personal characteristics, communication, and job satisfaction. Management Science Letters, 4(7), 1594-1604. https://doi.org/10.5267/j.msl.2014.5.028

6. Balthazard, P. A., Cooke, R. A., \& Potter, R. E. (2006). Dysfunctional culture, dysfunctional organization: Capturing the behavioural norms that form organizational culture and drive performance. Journal of Managerial Psychology, 21(8), 709-732. https://doi.org/10.1108/02683940610713253

7. Carriere, J., \& Bourque, C. (2009). The effects of organizational communication on job satisfaction and organizational commitment in a land ambulance service and the mediating role of communication satisfaction. Career Development International,14(1),29-49. https://doi.org/10.1108/13620430910933565

8. Daniels, K. \& Bailey, A.J. (1999). Strategy development processes and participation in decision making: predictors of role stressors and job satisfaction. Journal of Applied Management Studies. 8 (1): 27-42.

9. Fachrunnisa, O., \& Adhiatma, A. (2014). The role of workplace spirituality and employee engagement to enhance job satisfaction and performance. International Journal of Organizational Innovation, 7(1), 15-35.

10. Freeborn, D. K., \& Hooker, R. S. (1995). Satisfaction of physician assistants and other nonphysician providers in a managed care setting. Public Health Reports, 110(6), 714.

11. Fry, L. W. (2003). Toward a theory of spiritual leadership. The leadership quarterly, 14(6), 693-727. https://doi.org/10.1016/j.leaqua.2003.09.001

12. Gochhayat, J., Giri, V., \& Suar, D. (2017). Influence of Organizational Culture on Organizational Effectiveness: The Mediating Role of Organizational Communication. Global Business Review, 18(3), 691-702. https://doi.org/10.1177/0972150917692185 
13. Gutknect, M. D., \& Miller, J. R. (1990). The organizational and human sourcebook. New York: Press of America.

14. Hackman, J. R., \& Oldham, G. R. (1975). Development of the job diagnostic survey. Journal of Applied psychology, 60(2), 159. https://doi.org/10.1037/h0076546

15. Huang, Y. S., \& Chi, T. C. (2004). Internal marketing, organizational culture, job satisfaction, and operational performance: A study on international-class tourist hotels in Taiwan. J Manage Syst, 11(4), 485-507.

16. Hutcheson, G. and Sofroniou, N. (1999). The multivariate social scientist. London: Sage. https://doi.org/10.4135/9780857028075

17. Hwang, E. (2018). Effects of the organizational culture type, job satisfaction, and job stress on nurses' happiness: A cross-sectional study of the long-term care hospitals of South Korea. Japan Journal Of Nursing Science, 16(3), 263-273. https://doi.org/10.1111/jins.12235

18. Hynes, R., \& Mickahail, B. K. (2019). Leadership, culture, and innovation. In Effective and creative leadership in diverse workforces (pp. 65-99). Palgrave Macmillan, Cham. https://doi.org/10.1007/978-3-030-02348-5 4

19. Iqbal, S., Guohao, L., \& Akhtar, S. (2017). Effects of Job Organizational Culture, Benefits, Salary on Job Satisfaction Ultimately Affecting Employee Retention. Review of Public Administration And Management, 5(3), 1-7. https://doi.org/10.4172/2315-7844.1000229

20. Jaworski, B. J., \& Kohli, A. K. (1991). Supervisory Feedback: Alternative Types and their impact on salespeople's performance and satisfaction. Journal of Marketing Research, 28(2), 190-201. https://doi.org/10.1177/002224379102800206

21. Johnson, J. J., \& McIntye, C. L. (1998). Organizational culture and climate correlates of job satisfaction. Psychological Reports, 82(3), 843-850. https://doi.org/10.2466/pr0.1998.82.3.843

22. Joo, B. K. B., \& Park, S. (2009). Career satisfaction, organizational commitment, and turnover intention: The effects of goal orientation, organizational learning culture and developmental feedback. Leadership \& Organization Development Journal,31(6),482-500. https://doi.org/10.1108/01437731011069999

23. Kennerly, S.M. (1989). Leadership behaviour and Organizational Characteristics: implications for faculty satisfaction. Journal of Nursing Education, 28(5), 198-202. https://doi.org/10.3928/0148-4834-19890501-04

24. Kim, Y., Geun, H., Choi, S., \& Lee, Y. (2016). The Impact of Organizational Commitment and Nursing Organizational Culture on Job Satisfaction in Korean American Registered Nurses. Journal Of Transcultural Nursing, 28(6), 590-597. https://doi.org/10.1177/1043659616666326

25. Komah, I., Nugraemi, U., \& Usman, O. (2019). Effect of Leadership Style, Organizational Culture, Communication and Job Satisfaction of Employees Work Discipline. SSRN Electronic Journal. https://doi.org/10.2139/ssrn.3313467

26. Kossivi, B., Xu, M., \& Kalgora, B. (2016). Study on Determining Factors of Employee Retention. Open Journal Of Social Sciences, 04(05), 261-268. https://doi.org/10.4236/jss.2016.45029

27. Kotter, J.P. (2012) Corporate Culture and Performance, New York: The Free Press, pp.44-45.

28. Koustelios, A. (1996). The Influence of Organizational Culture on Job Satisfaction. Psychology, 3(2), 60-70.

29. Liu, Y., Aungsuroch, Y., \& Yunibhand, J. (2016). Job satisfaction in nursing: a concept analysis study. International Nursing Review, 63(1), 84-91. https://doi.org/10.1111/inr.12215

30. Locke, E. A. (1976). The nature and causes of job satisfaction. Handbook of industrial and organizational psychology, 1, 1297-1343.

31. Locke, P., \& Crawford, J. (1999). The relationship between commitment and organizational culture, subculture, leadership style and job satisfaction in organizational change and development. Leadership \& Organization Development Journal, 20(7), 365-374. https://doi.org/10.1108/01437739910302524

32. Maulidiyah, N. (2018). The Influence of Organizational Culture and Job Stress on Employees Performance by Job Satisfaction as an Intervening Variable in PT Binor Karya Mandiri Paiton Probolinggo. Asia Proceedings Of Social Sciences, 2(3), 141-145. https://doi.org/10.31580/apss.v2i3.350

33. McElroy, J., Smith-Miller, C. A., Madigan, C. K., \& Li, Y. (2016). Cultural awareness among nursing staff at an academic medical centre. JONA: The Journal of Nursing Administration, 46(3), 146-153. https://doi.org/10.1097/NNA.0000000000000315

34. Mengistu, M. M., \& Bali, A. G. (2015). Factors associated with job satisfaction among health care workers at public hospitals of West Shoa Zone, Oromia, Regional staff, Ethiopia: a cross-sectional study. Science journal of public health, 3(2), 161-167. https://doi.org/10.11648/j.sph.20150302.12

35. Mustafa, G., Glavee-Geo, R., \& Rice, P. (2017). Teamwork orientation and personal learning: The role of individual cultural values and value congruence. SA Journal Of Industrial Psychology, 43(1), 1-13. https://doi.org/10.4102/sajip.v43i0.1446

36. Nahar, B., Indratjahyo, H., \& Guswandi, G. (2020). The Influence Of Organizational Culture And Organizational Commitment To Employee Performance Through Job Satisfaction At Pt. Seoilindo Primatama Bekasi. International Journal Of Business And Social Science Research,1(1), 7-16. https://doi.org/10.33 642/ijbssr.v1n1p2

37. Parker, S. K., \& Sprigg, C. A. (1999). Minimizing strain and maximizing learning: the role of job demands, job control, and proactive personality. Journal of applied psychology, 84(6), 925. https://doi.org/10.1037/0021$\underline{9010.84 .6 .925}$ 
38. Pawirosumarto, S., Sarjana, P., \& Gunawan, R. (2017). The effect of work environment, leadership style, and organizational culture towards job satisfaction and its implication towards employee performance in Parador Hotels and Resorts, Indonesia. International Journal of Law And Management, 59(6), 1337-1358. https://doi.org/10.1108/IJLMA-10-2016-0085

39. Pincus, J. D. (1986). Communication satisfaction, job satisfaction, and job performance. Human communication research, 12(3), 395-419. https://doi.org/10.1111/j.1468-2958.1986.tb00084.x

40. Population Census. 2017. Government of Pakistan. Retrieved from http://www.pbs.gov.pk

41. Redding, J. (1997). Hardwiring the learning organization. Training \& Development, 51(8), 61-68.

42. Robbins, S.P. (1996). Organizational Behavior, concepts, controversies and applications. ( $7^{\text {th }}$ Ed.). Englewood Cliffs.v New Jersey: Prentice-Hall.

43. Schien, E.H. (2004). Organizational Culture and Leadership (Third Ed.). John Wiley \& Sons.

44. Schermerhorn, JR. 2000. Organizational Behavior. 7th Ed. Wiley, New York.

45. Smircich, L. 1983. Concepts of culture and organizational analysis. Administrative Science Quarterly, 28(3), 339-359. https://doi.org/10.2307/2392246

46. Testa, M. R. (1999). Satisfaction with organizational vision, job satisfaction and service efforts: an empirical investigation. Leadership \& Organization Development Journal, 20(3), 154-161. https://doi.org/10.1108/014 37739910268424

47. Tharp, B. M. (2009). Defining "Culture" and "Organizational Culture": From anthropology to the office. Interpretation a Journal of Bible and Theology, Har worth. Chicago.

48. Xuan Tran, B., Minh, H. V., \& Hinh, N. D. (2013). Factors associated with job satisfaction among commune health workers: implications for human resource policies. Global health action,6(1), 18619. : https://doi.org/10.3402/gha.v6i0.18619

49. Tumulty, G., Jernigan, I. E., \& Kohut, G. F. (1994). The impact of perceived work environment on job satisfaction of hospital staff nurses. Applied Nursing Research,7(2), 84-90. https://doi.org/10.1016/08971897(94)90037-X

50. Warr, P. (1994). A conceptual framework for the study of work and mental health. Work \& Stress, 8(2), 84-97. https://doi.org/10.1080/02678379408259982

51. West, MA (2002). Sparkling fountains or stagnant ponds: An integrative model of creativity and innovation implementation in workgroups. Applied psychology, 51 (3), 355-387. https://doi.org/10.1111/1464-0597.00951

52. World Health Organization. (2010). WHO global code of practice on the international recruitment of health personnel. Geneva: World Health Organization.

53. Witter, S., Ha, B. T. T., Shengalia, B., \& Vujicic, M. (2011). Understanding the 'four directions of travel': qualitative research into the factors affecting recruitment and retention of doctors in rural Vietnam. Human resources for health, 9(1), 1-14. https://doi.org/10.1186/1478-4491-9-20

54. Woodman, R. W., Sawyer, J. E., \& Griffin, R. W. (1993). Toward a theory of organizational creativity. Academy of management review, 18(2), 293-321. https://doi.org/10.5465/amr.1993.3997517

55. Zhang, X., \& Bartol, K. M. (2010). Linking empowering leadership and employee creativity: The influence of psychological empowerment, intrinsic motivation, and creative process engagement. Academy of management journal, 53(1), 107-128. https://doi.org/10.5465/amj.2010.48037118

56. Zhou, J. (2003). When the presence of creative coworkers is related to creativity: Role of supervisor close monitoring, developmental feedback, and creative personality. Journal of applied psychology, 88(3), 413. https://doi.org/10.1037/0021-9010.88.3.413 